\title{
Research on the construction of practical teaching system for accounting major in applied technology undergraduate universities
}

\author{
Zhang Dan ${ }^{1, a}$, Song Tianmei ${ }^{2, b,{ }^{*}}$ and Gao Ying ${ }^{3, c}$ \\ ${ }^{1}$ Xi'an University of Arts and Science/Xi'an Innovation college of Yan'an University , Xi'an, Shaanxi, \\ P.R. China \\ ${ }^{2}$ Xi'an Peihua University college of accounting, Xi'an, Shaanxi, P.R. China, \\ ${ }^{3}$ Xi'an University of Arts and Science school of Economics and Management, \\ Xi'an, Shaanxi, P.R. China \\ adanzhang1969@126.com , b287333328@QQ.com , ‘846500986@QQ.com
}

\begin{abstract}
Keywords: Applied technology ; Undergraduate; Accounting; Practical teaching system
\end{abstract}
\begin{abstract}
The new era of National Undergraduate Education Conference, the Secretary of Education Chen Baosheng said, undergraduate education is the life and development of higher education, we must adhere to the foundation, strengthens the first-class undergraduate education. The aim is to solve the problems existing in the cultivation of talents in the universities. The key to the teaching of applied technology universities depend on the construction and implementation of the practical teaching system. This paper based on the sort out existing problems, focuses on the guiding principles and related factors of practical teaching system construction in applied technology colleges. Finally, a case study on the construction of practical teaching system of accounting specialty in Xi'an University of Arts and Science was conducted.

The realization of the application technology of undergraduate education is the key to its practical te aching system construction and implementation, if we don't establish the practical teaching system $t$ hat meets the education objectives of applied technology undergraduate education, that meaningless for practice teaching. This also means that first thing to do is research on the construction of practic al teaching system of applied technology undergraduate.
\end{abstract}

\section{Introduction}

With the development of social economy and the standardization of financial management, the dem and for accounting professionals in various enterprises and institutions will be greatly increased. Ac counting has become a popular major in all walks of life. However, from the employers' reflection on graduates' employment and the related education and teaching research in Colleges and universities, there are still various problems in the training of accounting professionals, especially in the construction of practical teaching system. Schools attach importance to theory and neglect practice, and practice teaching becomes a subsidiary part of theory teaching, which is seriously inadequate in school hours; practical teaching content arrangement is not systematic, but concentrated on a few sporadic basic professional skills training, which can not be set up systematically, The practical teaching conditions are difficult to be fully supported, the construction of practical training rooms on campus is outdated, the construction of off-campus training platforms is insufficient, and the construction of practical teaching team is despised. Teachers on campus accept the traditional teaching, and their practical teaching ability is far from enough. As a result, students' professional skills are not strong enough, the application of knowledge is not enough, slow hands, cognitive ambiguity and other phenomena occur frequently. The practical teaching reform of Accounting Specialty in Applied Technical Undergraduate Colleges and universities needs to be carried out urgently. 


\section{Construction of practical teaching system of accounting major in applied technology undergraduate universities}

\subsection{Analysis of the key content of applied technology undergraduate universities}

\subsubsection{Analysis on the talent training objectives of applied technology undergraduates}

Applied technical university talents training face the province, radiate the surrounding area, according to local economic development and the needs of the industry for talents set up professional, Training advanced applicable talents mainly in technical management of engineers. Combines with the work post demand, these talents not only mastered the basic theory and professional knowledge well but also have ability to translate theory into actual production, and they can use the professional theory to analyze and solve practical production problems. In the process of talent training, we should focus on training students' ability to discover and solve problems, so that students can not only know what it is, understand why, but more importantly understand how to do it, and integrate operation design and management ability.

2.1.2 Analysis on the relationship between theory teaching and practice teaching in applied technology undergraduate college

According to the modern education system construction planning spirit in 2014-2020, application of technical undergraduate course colleges and universities, the emphasis in the process of talent training, major setting and industry requirements, curriculum content and professional standards, teaching process and production process three docking, promoting academic certificate and professional qualification certificate double certificate system, putting what you have learned into practice. While strengthening the theory teaching based on ability orientation, we should strengthen the practice teaching based on comprehensive skills and innovation orientation.

2.1.3 Content analysis of practical teaching system construction in applied technology undergraduate universities

The construction of the practical teaching system centers on the realization of the goal of professional personnel training mainly embodied in the framework of levels and contents, including practical content, such as in-class experimental training, curriculum design, graduation practice, graduation thesis, etc. Combining with the requirements of these contents, including the order of the project to carry out scientific arrangements, conditions for carrying out. Construction and quality control and so on.

\subsection{Personnel training program of applied technology undergraduate colleges and universities and the development of guiding ideology}

Applied Technological Undergraduate Colleges and universities should cultivate advanced skilled ta lents for the production, construction, service and management of industries and enterprises. They $\mathrm{s}$ hould scientifically orientate the types of personnel training specifications, pay attention to the trans formation of personnel training mode, speed up the reform of curriculum and teaching mode, form a differential development with the old undergraduate colleges and universities, and become undergr aduate level. The main force of secondary higher vocational education. In formulating the personnel training plan, we should take service as the purpose, adhere to one orientation (training and serving local economic and social development talents as the orientation, apply learning, basic quality and $t$ echnical application ability throughout the whole process of education), and construct three systems (discipline basis and specialty) according to two platforms (theory teaching platform and practice te aching platform). The curriculum system of Vocational education, the teaching system of cultivating practical ability and the general course system should be combined in four ways (the combination o f general education and professional education, theory and practice, in-class and out-of-school, in-sc hool and out-of-school), so as to form the "four" mode of cultivating applied talent, that closely relying on the needs of local and regional economic and social development. We should cultivate corresponding talents. 


\section{Accounting major of Xi'an University of Arts and Science, practical teaching system case}

Xi'an University of Arts and Science is a pilot school for transformation and development determined by the department of education. It has a transformation and development plan. Xi'an University of Arts and Science of professional accounting, to adapt to the transformation of school development strategy actively, on the talents cultivation orientation, about cultivating local applied, the internationalization of the goal of high quality application and technology talents, it's clear positioning, development goals clear, planning scientific and reasonable, conform to the requirements of the national transformation development, for local economic and social development needs.

\subsection{Guiding ideology of talent cultivation}

Accounting is the key major of Xi'an University of Arts and Science, in the creation of the first-class professional, first-class research team, first-class course application transformation, and the first-class teaching environment, that guidelines are focus on the cultivation of applied technical talents, take professional construction as the leading role, powered by the transformation of development, strengthen the teaching staff with school-enterprise construction.

\subsection{Talent training objective positioning}

Accounting is a subject of business administration, which is a major with strong applicability. The accounting specialty of Xi'an University of Arts and Sciences is based on Shaanxi, facing the northwest, cultivating the all-round development of morality, intelligence, physique and beauty, mastering the basic knowledge, basic methods and skills of modern management theory, economics and accounting. With strong accounting, auditing, financial management and computer practical operation ability, can be in small and medium-sized enterprises, financial industry, international accounting, non-profit organizations engaged in accounting practice and related management of high-quality application of technical personnel.

\subsection{Construction of practical teaching system}

Accounting specialty closely centers on the orientation of talent cultivation, adheres to the market-oriented, and aims to cultivate talents needed by the market, and strengthens the construction of Applied Technology courses. Guided by the concept of collaborative innovation, this paper explores the "three layers of five" practical teaching system for accounting specialty, and establishes a " three layers of five" practical teaching platform for accounting specialty training, which integrates "university collaboration, Institute collaboration, institute-government collaboration, Institute-site collaboration, institute-enterprise collaboration and international communication". And the practice teaching platform to create "science formation, field work, and special training" series meet the requirements of the accounting profession training "work-integrated learning, double certificates" training mode.

\subsection{Construction of practice platform}

The practice teaching cannot be carried out without the support of the platform. The major of accounting has developed three levels and five levels, and the construction of the practice teaching platform will form the basic cognitive and validation experiment, the simulation experiment of professional position skills, the university-enterprise co-construction and production is called as one entity, and the three levels. The training of students' practical ability, basic cognition and verification experiment, vocational post skills simulation experiment, university-enterprise joint production and education integrated entity, the opening and sharing of the Internet plus teaching resources, the Omni-directional three-dimensional platform at five levels. It can not only guarantee the training of students' basic skills, but also combine with the development of industrial industry to improve students' professional application skills.

\subsection{Practice teacher' rank establishment}

Pay attention to the cultivation, training and optimization of the practice teaching team, and adopt 
various forms to improve the quality of the teachers, so as to ensure the implementation of the practice teaching requirements, thus ensuring the effect of the practice teaching. For the improvement of the quality of teachers, the college shall make good arrangement and utilization of existing resources, formulate effective measures, mobilize the initiative of relevant personnel, strengthen training and requirements, improve the quality of teachers, and strengthen team building. That is: external training, internal training and external training.

In a word, in order to solve the problems existing in the training of accounting talents in univer sities, we should take the concept of collaborative innovation as the guide, explore the practical teac hing system of collaborative innovation and "three-tier and five-tier" and establish the accounting s pecialty that combines "university collaboration, Institute collaboration, institute-government collab oration, Institute-site collaboration, institute-enterprise collaboration and international exchange". $\mathrm{O}$ nly by cultivating models can we create "three levels and five levels" practical teaching system.

\section{Acknowledgement}

Xi'an University of Arts and Sciences 2017 school-level education and teaching reform research pro ject, 2018 teaching results cultivation project (No. JG2017007)

\section{Reference}

[1] The State Council Information Office Of the People's Republic of China. Decision of the State Council on accelerating the development of modern vocational education [EB/OL].http://www.scio.gov.cn/ztk/xwfb/2014/gxbjhzyjyggyfzqkxwfbh/xgbd31088/Documen t/1373573/1373573_1.htm

[2] Secretary of Education [EB/OL]. http://edu.southcn.com/e/2018-06/23/content_182325086.htm

[3] Xu Aifei. Exploration of practical teaching of accounting specialty based on practical personnel training [J]. Contemporary Education Research and Teaching Practice.2017

[4] Huang Heshu, Zhang Hong, Cheng Min. The Exploration and Practice of Experimental Teaching in Administrative Accounting Talents Training----With Accounting Major of Anhui University for Example [J]. Journal of Shanxi University of Finance and Economics, 2016 